\title{
KORELASI ANTARA KEBIASAAN MEMBACA DENGAN KEMAMPUAN MEMBACA PEMAHAMAN PESERTA DIDIK SMK MUHAMMADIYAH TAWANG REJO
}

\author{
Eka Putri Rahayu ${ }^{1^{*}}$ \\ Program Studi Pendidikan Bahasa dan Sastra Indonesia \\ STKIP Nurul Huda OKU Timur \\ E-mail: Ekaputrirahayu78@gmail.com
}

\begin{abstract}
Abstrak
Kebiasaan membaca menjadi salah satu fakor penting dalam memahami isi bacaan. Peserta didik yang memiliki kebiasaan membaca maka ia memiliki kemampuan memahami isi bacaan dengan baik. Penelitian ini dilatarbelakangi oleh rendahnya kemampuan pemahaman dalam membaca, kurangnya minat membaca, kurangnya kesadaran untuk membaca, dan belum adanya kegiatan yang mendorong untuk membiasakan membaca. Penelitian bermaksud untuk mencari ada tidaknya hubungan antara kebiasaan membaca dengan kemampuan membaca pemahaman pada peserta didik yang dilakukan di SMK Muhammadiyah Tawang Rejo. Jenis penelitian yang digunakan yaitu kuantitatif, menggunakan metode deskriptif, dengan pendekatan korelasional. Hasil analisis penelitian ini yaitu terdapat korelasi antara kebiasaan membaca dengan kemampuan membaca pemahaman pada peserta didik, dengan nilai signifikansi $0,002<0,05$. Nilai $r$ hitung sebesar 0,550 , menunjukkan keeratan hubungan kebiasaan membaca dengan kemampuan membaca pemahaman kedalam tingkat sedang. Nilai $r$ hitung 0,550 menunjukkan angka positif yang berarti semakin tinggi kebiasaan membaca maka semakin tinggi pula kemampuan membaca pemahaman peserta didik.
\end{abstract}

Kata kunci: Kebiasaan membaca, kemampuan membaca pemahaman, dan peserta didik.

\section{PENDAHULUAN}

Ruang lingkup pendidikan baik formal maupun non formal tidak terlepas dari bahasa. Tidak hanya di dalam pendidikan, dalam kehidupan sehari-hari bahasa juga sangat penting. Bahasa digunakan sebagai alat komunikasi untuk menyampaikan suatu gagasan atau pikiran seseorang. Bahasa juga sangat berkaitan dengan keterampilan yang sering disebut keterampilan berbahasa. Keterampilan bahasa terdiri dari komponen mendengarkan, berbicara, membaca, dan menulis. Keempat komponen tersebut saling berkaitan karena diperoleh individu melalui urutan yang teratur, mulai dari masa bayi yaitu menyimak, kemudian berbicara, membaca, dan barulah menulis. Keterampilan berbahasa ini sangat penting dikuasai dengan baik oleh setiap individu untuk berkomunikasi dengan baik dan jelas agar apa yang disampaikan dapat diterima baik pula oleh individu lain. Hal ini sependapat dengan Tarigan (2008:1) "Semakin terampil seseorang berbahasa, semakin cerah dan jelas pikirannya."

Salah satu keterampilan yang penting untuk dikuasai baik dalam kehidupan terutama dalam dunia pendidikan adalah membaca. Segala informasi dan ilmu pengetahuan didapat melalui membaca. Membaca merupakan salah satu kegiatan yang dilakukan seseorang untuk memperoleh suatu pesan melalui bahsa tulis. Menurut Alderson (dikutip oleh Nurhadi 2017:1) "Membaca adalah proses berpikir. Membaca adalah aktivitas mental yang melibatkan proses berpikir." Untuk itu, membaca tak hanya sekedar melihat bacaan tetapi memahami isi bacaan tersebut.

Keterampilan membaca merupakan dasar untuk menguasai bahasa yang perlu dikembangkan, baik bahasa lisan maupun bahasa tulis. Dalam pendidikan membaca merupakan salah satu bagian yang paling penting untuk menunjang proses kegiatan belajar mengajar, karena segala informasi dan 
KORELASI ANTARA MEMBACA DENGAN KEMAMPUAN MEMBACA.... |27 ilmu pengetahuan tidak hanya dari apa yang disampaikan oleh guru tetapi dari membaca juga. Pemahaman siswalah yang akan menjadi tolok ukur keberhasilan proses belajar mengajar.

Sumber informasi dan pengetahuan sangat banyak terdapat di dalam media tulis. Oleh Karena itu, setiap pembaca diharapkan dapat membaca dengan baik agar informasi dalam bacaan dapat diterima dan dipahami dengan baik.Pemahaman itulah yang menjadi bekal keberhasilan seseorang. Membaca pemahaman merupakan kegiatan yang dilakukan seseorang untuk memperoleh informasi seluas-luasnya serta untuk meningkatkan ilmu pengetahuan dan teknologi. Menurut Irwansyah (2013:42) "Membaca pemahaman dapat diartikan sebagai serangkaian proses yang dilakukan pembaca untuk menemukan informasi dan memahami informasi yang terkandung dalam sebuah teks bacaan."

Membaca pemahaman sangatlah penting, tak hanya dikalangan pelajar namun untuk semua kalangan. Sayangnya kebiasaan membaca ini tidak banyak diminati, sehingga membuat kemampuan membaca anak Indonesia tergolong rendah. Hasil tes Programme for International Student Assessment (PISA) 2015 yang diumumkan pada tahun 2016 (dikutip oleh Antoro 2017: 8) yakni mengenai minat membaca menempatkan Indonesia di urutan 64 dari 72 negara survey.

Keterampilan membaca memiliki kedudukan paling penting dalam pendidikan, karena untuk menunjang keberhasilan tujuan kegiatan belajar mengajar. Namun, tidak banyak siswa yang memiliki kebiasaan membaca sehingga kemampuan membacanya rendah. Banyak siswa membaca hanya ketika diminta guru untuk membaca. Bahkan terkadang buku-buku yang dipinjamkan sekolah ditinggal di dalam laci meja kelas.

Berdasarkan hasil observasi penelitian di SMK Muhammadiyah Tawang Rejo ada beberapa permasalahan yaitu: 1) kurangnya minat membaca peserta didik, 2) kurangnya kesadaran membaca peserta didik, 3) nilai kemampuan membaca pemahaman rata-rata rendah, dan 4) belum adanya program pembiasaan membaca di sekolah. Kebiasaan membaca ini menjadi faktor penentu peserta didik dalam pemahaman isi bacaan. Peserta didik yang memiliki kebiasaan untuk membaca maka pemahamannya juga baik. Begitupun peserta didik yang tidak membiasakan membaca cenderung pemahamannya juga rendah.

Pemahaman dalam membaca sangat penting, karena membaca tanpa memahami isi bacaan maka kita tidak akan mendapat ilmu baru dari yang telah kita baca. Membaca pemahaman yang baik akan terbentuk ketika seseorang telah memiliki motivasi untuk membaca, dan jika motivasi itu terus ada dalam diri seseorang maka menjadi suatu kebiasaan. Kebiasaan membaca tersebut menjadi tingkat pengetahuan dalam memahami isi bacaan. Jadi, kebiasaan membaca sangat berpengaruh untuk seseorang dapat memiliki kemampuan pemahaman dalam membaca. Seperti halnya yang dikatakan oleh Hairi (1013:14) "terdapat hubungan yang positif antara kebiasaan membaca dengan kemampuan membaca pemahaman."

Berdasarkan latar belakang di atas, peneliti berminat untuk meneliti hubungan antara kebiasaan membaca dengan kemampuan membaca pemahaman. Penelitian akan dilakukan di SMK Muhammadiyah Tawang Rejo tahun ajaran 2018/2019. Penelitian menggunakan kelas XI sebagai populasi dan kelas yang terpilih untuk menjadi sampel penelitian yaitu kelas XI Tata Niaga.

\section{METODE PENELITIAN}

Jenis penelitian yang digunakan penelitian ini adalah kuantitatif. Menurut Esti (2011:31) "Penelitian kuantitatif adalah prosedur penelitian yang menghasilkan data kuntitatif berupa angkaangka." Penelitian ini menggunakan metode deskriptif dengan pendekatan korelasional. Menurut Sugiyono (2017:207) "Deskriptif adalah analisis data dengan menggambarkan data yang terkumpul sebagaimana adanya tanpa bermaksud membuat kesimpulan yang berlalu untuk umum." Sedangkan, pendekatan korelasional merupakan penelitian yang dilakukan untuk mengetahui hubangan antar variabel (Arikunto, 2014:313).

Sampel dalam penelitian menggunakan simple random sampling untuk memudahkan peneliti mengambil data penelitian. Menurut Sugiyono (2017:120) "Simple random sampling adalah teknik penggambilan anggota sampel dari populasi secara acak tanpa memperhatikan strata dalam populsi." Pengambilan sampel dalam penelitian ini dilakukan dengan cara mengundi tiga kelas dari kelas XI yang ada, kemudian dari undian tersebut terpilih satu kelas untuk dijadikan sampel penelitian Sedangkan teknik pengumpulan data menggunakan angket dengan acuan skala likert untuk mengetahui kebiasaan membaca, dan menggunakan tes berupa tes pilihan ganda untuk mengetahui 


\section{Hasil}

\section{HASIL DAN PEMBAHASAN}

\section{Uji Normalitas}

Uji normalitas dalam penelitian ini menggunakan teknik kolmogrov-smirno. Uji normalitas ini digunakan untuk mengetahui normal tidaknya data yang menjadi penelitian. Suatu data dapat dikatakan berdistribusi normal apabila nilai signifikasi lebih besar dari 0,05 . Berikut hasil uji normalitas menggunakan program spss versi 16.

Tabel 1. Uji Normalitas

\begin{tabular}{|c|c|c|c|c|c|c|}
\hline \multicolumn{7}{|c|}{ Tests of Normality } \\
\hline & \multicolumn{3}{|c|}{ Kolmogorov-Smirnov $^{\mathrm{a}}$} & \multicolumn{3}{|c|}{ Shapiro-Wilk } \\
\hline & Statistic & Df & Sig. & Statistic & Df & Sig. \\
\hline kebiasaan membaca & .130 & 29 & $.200^{*}$ & .933 & 29 & .064 \\
\hline $\begin{array}{l}\text { kemampuan } \\
\text { pemahaman }\end{array}$ & .145 & 29 & .125 & .948 & 29 & .159 \\
\hline \multicolumn{7}{|l|}{ a. Lilliefors Significance Correction } \\
\hline *. This is a lower bound of the true $\mathrm{s}$ & icance. & & & & & \\
\hline
\end{tabular}

Berdasarkan hasil perhitungan di atas, diketahui bahwa nilai signifikansi kebiasaan membaca sebesar 0,200 . Data yang diperoleh dari variabel kebiasaan membaca berdistribusi normal karena $0,200>0,05$. Sedangkan nilai signifikansi kemampuan membaca pemahaman sebesar 0,125 . Maka data variabel kemampuan membaca pemahaman berdistribusi normal karena 0,125>0,05.

\section{Uji Linieritas}

Uji linieritas digunakan untuk mengetahui ada tidaknya hubungan yang linier pada variabel $X$ dan variabel Y. Dikatakan linier jika nilai signifikansi lebih besar dari 0,05 . Hasil perhiungan uji linieritas dalam penelitian ini niai signifikansi sebesar 0,218. Disimpulkan bahwa kedua variabel bersifat linier karena nilai signifikansi 0,218 $>0,05$. Berikut hasil perhitungan menggunakan spss versi 16 dengan bantuan komputer:

Tabel 2. Uji Linieritas

\begin{tabular}{|c|c|c|c|c|c|c|c|c|}
\hline \multicolumn{9}{|c|}{ ANOVA Table } \\
\hline & & & & $\begin{array}{l}\text { Sum } \\
\text { Squares }\end{array}$ & df & $\begin{array}{l}\text { Mean } \\
\text { Square }\end{array}$ & $\mathrm{F}$ & Sig. \\
\hline \multirow{5}{*}{$\begin{array}{l}\text { kemampuan } \\
\text { pemahaman } \\
\text { membaca }\end{array}$} & $\begin{array}{r}\text { membaca } \\
* \quad \text { kebiasaan }\end{array}$ & $\begin{array}{l}\text { Between } \\
\text { Groups }\end{array}$ & $\begin{array}{l}\text { (Combine } \\
\text { d) }\end{array}$ & 1732.543 & 19 & 91.186 & 2.478 & .082 \\
\hline & & & Linearity & 625.206 & 1 & 625.206 & $\begin{array}{l}16.98 \\
7\end{array}$ & .003 \\
\hline & & & $\begin{array}{l}\text { Deviation } \\
\text { from } \\
\text { Linearity }\end{array}$ & 1107.337 & 18 & 61.519 & 1.671 & .218 \\
\hline & & Within Groups & & 331.250 & 9 & 36.806 & & \\
\hline & & Total & & 2063.793 & 28 & & & \\
\hline
\end{tabular}

\section{Analisis Korelasi}

Analisis korelasi bertujuan untuk mengetahui ada tidaknya hubungan antara variabel bebas dan variabel terikat. Ketentuan nilai signifikansi analisis korelasi adalah Jika nilai signifikansi $<0,05$ maka dapat dikatakan berkorelasi (berhubungan) dan jika nilai signifikansi $>0,05$ maka nilai tidak berkorelasi (tidak ada hubungan). Untuk mengetahui keeratan hubungan antara variabel $X$ yaitu kebiasaan membaca dan Variabel $Y$ yaitu kemampuan membaca pemahaman dapat dilihat tabel pedoman interpretasi berikut: 
Tabel 3. Pedoman Interpretasi Koefisien Korelasi

\begin{tabular}{|l|l|}
\hline $\begin{array}{l}\text { Interval } \\
\text { Koefisiensi }\end{array}$ & Tingkat Hubungan \\
\hline $0,00-0,199$ & Sangat rendah \\
\hline $0,20-0,399$ & Rendah \\
\hline $0,40-0,599$ & Sedang \\
\hline $0,60-0,799$ & Kuat \\
\hline $0,80-1,000$ & Sangat kuat \\
\hline
\end{tabular}

(Sugiyono, 2017:257)

Berikut adalah perhitungan analisis korelasi menggunakan SPSS versi 16 dengan bantuan komputer:

Tabel 4. Analisis Korelasi

\begin{tabular}{llll}
\hline Correlations & & & \\
\hline & & $\begin{array}{l}\text { kebiasaan } \\
\text { membaca }\end{array}$ & $\begin{array}{l}\text { kemampuan } \\
\text { membaca } \\
\text { pemahaman }\end{array}$ \\
$\begin{array}{llll}\text { kebiasaan } \\
\text { membaca }\end{array}$ & $\begin{array}{l}\text { Pearson } \\
\text { Correlation }\end{array}$ & 1 & $.550^{* *}$ \\
& Sig. (2-tailed) & & .002 \\
kemampuan & $\mathrm{N}$ & 29 & 29 \\
$\begin{array}{l}\text { membaca } \\
\text { pemahaman }\end{array}$ & $\begin{array}{l}\text { Pearson } \\
\text { Correlation }\end{array}$ & $.550^{* *}$ & 1 \\
$* *$ Sig. (2-tailed) & .002 & \\
\hline
\end{tabular}

Hasil perhitungan analisis korelasi diatas dapat disimpulkan bahwa nilai signifikansi 0,002 < 0.05 maka dapat dikatakan terdapat korelasi antara kebiasaan membaca dengan kemampuan membaca pemahaman. Berdasarkan derajat hubungan tedapat nilai 0,550 dapat dilihat pada tabel interprestasi, maka dapat disimpulkan bahwa 0,550 korelasi sedang atau cukup.

Setelah diperoleh hasil perhitungan analisis korelasi, maka diketahui sumbangan variabel $X$ terhadap variabel $Y$. Diketahui nilai $r$ hitung atau pearson correlations sebesar 0,550 . Nilai $r$ hitung bernilai positif yang berarti sumbangan variabel $X$ terhadap variabel $Y$ bernilai positif. Semakin meningkatnya kebiasaan membaca maka meningkat pula kemampuan membaca pemahamannya.

\section{Pembahasan}

Kebiasaan membaca merupakan suatu kegiatan membaca yang dilakukan individu secara terus-menerus dan telah mendarah daging. Membiasaan diri sendiri untuk membaca adalah hal yang penting, karena membaca merupakan aspek yang sangat berpengaruh dalam kehidupan. Kebiasaan membaca menjadi salah satu faktor yang mempengaruhi seseorang dalam memahami isi bacaan. Ketika kebiasaan membaca sudah terbentuk pada diri seseorang maka akan terbentuk pula kemampuan untuk memahami isi bacaan dengan baik.

Membaca menjadi salah satu hal yeng penting, karena berbagai aspek kehidupan melibatkan membaca. Membaca akan sangat bermanfaat jika disertai dengan pemahaman. Pemahaman itulah yang akan menjadi bekal ilmu yang menghantarkan berbagai wawasan. Oleh karena itu, membudayakan membaca untuk memperoleh ilmu pengetahuan sangat dianjurkan terutama bagi pelajar.

Penelitian ini membahas tentang ada tidaknya hubungan antara kebiasaan membaca dengan kemampuan membaca pemahaman, yang menghipotesiskan Ha diterima jika ada hubungan yang signifikan antara kebiasaan membaca dengan kemampuan membaca pemahaman. Penelitian Eka Putri Rahayu 
dilakukan di SMK Muhammadiyah Tawang Rejo. Teknik pemilihan sampel kelas yaitu menggunakan teknik simple random sampling, yang mana kelas dipilih secara acak dan bersifat yang homogen. Cara yang digunakan untuk memilih kelas dengan menggundi 3 kelas XI yaitu kelas AP, TN, dan MM. kelas yang terpilih dari hasil undian yaitu kelas XI Tata Niaga, dengan jumlah 29 responden. Penelitian ini terdapat dua variabel yaitu variabel bebas (kebiasaan membaca) dan variabel terikat kemampuan membaca pemahaman).

Setelah dilakukan perhitungan menggunakan program spss versi 16, ditemukan hasil perhitungan pada kedua variabel. Hasil perhitungan variabel kebiasaan membaca yaitu nilai minimum sebesar 63 dan maksimum sebesar 99. Nilai mean diperoleh sebesar 86,76 dengan standar deviasi sebesar 9,848. Kriteria kelompok pada variabel kebiasaan membaca yaitu kategori tinggi $17,2 \%$, kategori rendah $17,2 \%$, dan kategori sedang $65,5 \%$. Disimpulkan bahwa kriteria kelompok variabel kebiasaan membaca dikategorikan sedang.

Hasil perhitungan variabel kemampuan membaca pemahaman ditemukan nilai minimum 40 dan maksimum 75. Nilai mean diperoleh sebesar 51,72 sedangkan standar deviasi sebesar 7,823. Kemudian kriteria kelompok pada variabel kemampuan membaca pemahaman yaitu kategori tinggi $10,3 \%$, rendah $13,8 \%$, dan sedang $75,9 \%$. Disimpulkan kriteria kelompok kemampuan membaca pemahaman dikategorikan dalam kategori sedang.

Selanjutnya dari hasil perhitungan analisis korelasi variabel kebiasaan membaca dengan kemampuan membaca pemahaman dapat disimpulkan berkorelasi atau memiliki hubungan. Hal ini dibuktikan dengan hasil korelasi bahwa nilai signifikansi $0,010<0,05$, yang mana nilai signifikansi lebih kecil dari nilai tabel. Perhitungan nilai tersebut berarti hipotesis diterima.Kemudian derajat hubungan kedua variabel sebesar 0,469 , maka dikatakan bahwa korelasi kedua variabel tersebut sedang atau cukup.

Hasil analisis korelasi juga menunjukkan sumbangan variabel $\mathrm{X}$ terhadap Variabel $\mathrm{Y}$. Apakah semakin besar sumbangan variabel $x$ semakin besar pengaruhnya terhadap variabel $Y$. Diperoleh nilai $r$ hitung sebesar 0,469 . Nilai tersebut bernilai positif yang artinya semakin meningkat kebiasaan seseorang dalam membaca maka semakin meningkat pula kemampuan membaca pemahamannya.

\section{PENUTUP}

Berdasarkan hasil penelitian dan pembahasan yang dilakukan, maka dapat disimpulkan bahwa kemampuan membaca pemahaman ada kaitannya atau ada hubungan dengan kebiasaan membaca. Hal ini dibuktikan dari hasil analisis yang menggunakan tes kebiasaan membaca berupa angket dan kemampuan membaca pemahaman berupa tes pilihan ganda. Tes dilakukan di SMK Muhammadyah Tawang Rejo Kelas XI Tata Niaga, dengan jumlah 29 responden. Hasil analisis menunjukkan adanya hubungan antara kebiasaan membaca dengan kemampuan membaca pemahaman peserta didik.

Hasil analisis korelasi menunjukkan nilai signifikansi sebesar 0,002. Nilai signifikansi tersebut lebih kecil dari nilai tabel $(0,002<0.05)$ yang berarti terdapat koelasi antara kebiasaan membaca dengan kemampuan membaca pemahaman, dan hipotesis diterima. Derajat hubungan yaitu cukup dengan nilai Pearson Correlation 0,550. Nilai $r$ hitung tesebut bernilai positf dan dapat disimpulkan semakin meningkatnya kebiasaan membaca maka meningkat pula kemampuan membaca pemahamannya.

\section{DAFTAR PUSTAKA}

Agustina, Refni. 2014. Hubungan Kebiasaan Membaca dengan Hasil Belajar Bahasa Indonesia Siswa Kelas V SD Negeri 69 Kota Bengkulu. Skripsi. Tidak Diterbitkan. Fakultas Keguruan dan IImu Pendidikan: Universitas Bengkulu.

Ahuja, Pramilia dan G. C Ahuja.2010. Membaca Secara Efektif dan Efisien. Bandung: PT Kiblat Buku Utama.

Antoro, Billy. 2017. Gerakat Literasi Sekolah, Dari Pucuk Hingga Akar, Sebuah Refleksi. Jakarta: Direktorat Jendral Pendidikan Dasar dan Menengah Kementrian Pendidikan dan Kebudayaan.

Arikunto, Suharsimi. 2014. Prosedur Penelitian, Suatu Pendekatan Praktik. Jakarta: Rineka Cipta.

Eka Putri Rahayu 
Arikunto, Suharsimi. 2016. Manajemen Penelitian. Jakarta: Rineka Cipta.

Darmawati, Uti dan Y. Budi Artati. 2015. Detik-Detik Ujian Nasional Bahasa Indonesia Tahun Pelajaran 2014/2015. Klaten: PT Intan Pariwara.

Djojosuroto, Kinayati dan M.L.A Sumaryati. 2010. Prinsip-Prinsip Dasar Penelitian Bahasa dan Sastra. Bandung: Yuansa.

Hairi, Syawaludin, et al. Hubungan Kebiasaan Membaca dengan Kemampuan membaca Pemahaman Siswa Kelas XI SMK Mandiri Pontianak Tahun 2013. Jurnal Pendidikan dan pembelajaran, 3.6.

Hartono. 2008. SPSS 16.0 Analisis Data Statistika dan Penelitian. Yogyakarta: Pustaka Pelajar.

Irwansyah, Nur dan Mukhtar. 2013. Buku Mata Kuliah Membaca. Tanggerang: PT Pustaka Mandiri.

Ismail, Ismail. Korelasi antara Kebiasaan Membaca dengan Kemampuan Membaca Pemahaman Siswa Kelas VIII SMP Negeri 1 Rambah. Edu Research, 2016, 5.1:63-66.

Ismawati, Esti. 2011. Metode Penelitian Pendidikan Bahasa \& Sastra. Surakarta: Yumna Pustaka.

Najamiah. 2017. Pengaruh Minat Baca Terhadap Kemampuan Memahami Bacaaan Peserta Didik Kelas VI SD Negeri Gunung Sari 1 Kec.Rappocini Kota Makasar. Skripsi. Tidak Diterbitkan. Fakultas Tarbiyah dan Keguruan: UIN Alahuddin Makasar.

Nurhadi. 2010. Bagaimana Meningkatkan Kemampuan Membaca, Suatu Teknik Memahami Literatur yang Efisien. Bandung: Sinar Baru Algensindo.

Priyatni, Endah Tri dan Nurhadi. 2017. Membaca Kritis dan Literasi Kritis. Tanggerang: Tira Smart.

Purnamasari, Dewi. 2013. Hubungan Antara Kebiasaan Membaca dengan Pemahaman Bacaan Siswa Kelas VIII SMP di Kecamatan Kalasan Sleman. Skripsi. Tidak Diterbitkan. Fakultas Bahasa dan Seni: Universitas Negeri Yogyakarta.

Rahim, Farida. 2008. Pengajaran Membaca Di Sekolah Dasar. Jakarta: PT Bumi Aksara.

Sugiyono. 2015. Statistika untuk Penelitian. Bandung: Alfabeta.

Sugiyono. 2017. Metode Penelitian Pendidikan Pendekatan Kuantitatif, Kualitatif, dan R\&D. Bandung: Alfabeta.

Suryanto dan Siswanto. 2018. Metode Penelitian Kuantitatif Korelasional. Klaten: Bossscript.

Tampubolon, D.P. 2015. Kemampuan Membaca, Teknik Membaca Efektif dan Efisien. Bandung: CV Angkasa.

Tarigan, Henry Guntur. 2008. Membaca Sebagai Suatu Keterampilan Berbahasa. Bandung: Angkasa Bandung. 